\title{
Stand Up Comedy, Retorika Generasi Milenial
}

\author{
Ifah Atur Kurniati \\ Sekolah Tinggi Ilmu Komunikasi Profesi Indonesia.
}

\begin{abstract}
Abstrak
Generasi milenial hadir dengan berbagai fenomena komunikasi baru. Generasi yang sarat ekspresi. Mengungkapkan kegelisahan dan kritik melalui media baru. Stand Up Comedy, merupakan gaya baru dalam berkomunikasi di ruang public. Mulai trend di Indonesia pada 10 tahun terakhir, Stand Up Comedy kini tengah menjadi sebuah hal yang awam dan diterima di kalangan milenial. Stand $U p$ Comedy dapat dilihat dari sisi retorika, yakni adalah seni mengatur komposisi katakata dan kesan menarik yang ditujukan untuk mempengaruhi dan mengubah pendengar. Studi retorika sesungguhnya adalah bagian dari disiplin ilmu komunikasi, karena di dalam retorika terdapat penggunaan simbol-simbol yang dilakukan oleh manusia.

Retorika berhubungan erat dengan komunikasi persuasi, sehingga retorika juga dapat di katakan suatu seni dari mengkonstruksikan argument. Seorang comedian (pembicara) yang tertarik untuk membujuk pendengarnya untuk mempertimbangkan tiga bukti retoris yaitu logika (logos), emosi (pathos) dan etika/kredibilitas (ethos). Stand Up Comedy dalam pertunjukannya di hadapan public tidak bisa lepas dari tiga bukti retoris tersebut. Metode penelitian ini menggunakan studi kasus eksploratif. Alasan yang mendasar penggunaan pendekatan tersebut karena permasalahan yang ada membutuhkan penggalian mendalam terhadap fakta dan data.
\end{abstract}

Keywords: Stand Up Comedy, Retorika modern, milenial.

\section{Abstract}

Millennials come with a variety of new communication phenomena. A generation full of expression. Reveal anxiety and criticism through new media. Stand Up Comedy, is a new style of communicating in the public space. Starting the trend in Indonesia in the last 10 years, Stand Up Comedy is now becoming a common thing and accepted by millennials. Stand Up Comedy can be seen from the side of rhetoric, which is the art of arranging the composition of words and interesting impressions aimed at influencing / changing listeners. Rhetoric studies are actually part of communication disciplines, because in the rhetoric there are uses of symbols carried out by humans.

Rhetoric is closely related to persuasion communication, so rhetoric can also be said of an art from constructing an argument. A comedian, a speaker who is interested in persuading his audience to consider three rhetorical proofs namely 
logic (logos), emotion (pathos) and ethics / credibility (ethos). Stand Up Comedy in its performance before the public can not be separated from the three rhetorical evidence. This research method uses explorative case studies. The underlying reason for using this approach is because the existing problems require deep exploration of facts and data.

Keywords: Stand Up Comedy, rhetoric, public speaking

\section{Pendahuluan}

Millennial generation atau generasi Y juga akrab disebut generation me atau echo boomers. Secara harfiah memang tidak ada demografi khusus dalam menentukan kelompok generasi yang satu ini. Namun, para pakar menggolongkannya berdasarkan tahun awal dan akhir. Penggolongan generasi Y terbentuk bagi mereka yang lahir pada 1980 - 1990, atau pada awal 2000, dan seterusnya.

Generasi millennial cenderung berani menyuarakan pendapat dan isu-isu social di ranah publik dengan cara-cara baru yang lebih kreatif. Kembali ke hakekat ilmu retorika, bahwa salah satu tujuan dari retorika adalah mempengaruhi publik, maka cara-cara yang digunakan para generasi millennial ini pun juga memiliki tujuan tersebut. Bahkan mereka juga menambah satu tujuan lagi yaitu merubah prilaku. Generasi millennial punya mindset yang lebih dibanding dengan para pendahulunya dalam hal retorika. Mereka juga menambahkan unsur hiburan dan sekaligus aktualisasi diri di dalamnya.

Retorika ala millennial menambahkan unsur hiburan di dalamnya, itu artinya, si retoris harus mampu untuk menciptakan tawa dalam retorika. Maka pilihan generasi millennial jatuh kepada seni lawak (Comedy). Selanjutnya, gabungan ini awam disebut Stand Up Comedy. Sebuah gaya baru dalam retorika. Generasi muda memiliki ketertarikan terhadap stand up comedy ini, namun sayangnya sebagian besar hanya melihat dari sisi hiburan semata. Tanpa tahu bahwa stand comedy bukan comedy yang disuguhkan dengan hasil akhir tawa, melainkan ada tujuan lain di dalamnya. Perubahan opini, prilaku, dan sikap. Para Comedian dituntut peka akan isu sosial dan membawakannya di hadapan publik dengan menghibur. Tujuan dari penulisan karya ilmiah ini adalah: (1) Untuk mengetahui dan memahami Stand Up Comedy sebagai Retorika Generasi Millenial, (2) Sebagai masukan bagi para Comics dan Stand Up Comedy di Indonesia 


\section{Kajian Literatur \\ Teori Retorika}

Little John (dalam Morissan, 2013) mendefinisikan retorika sebagai "The art of contructing argument and speechmaking" (seni membangun argumentasi dan seni berbicara). Aristoteles mengembangkan teori yang berguna bagi sophisdalam public speaking. (Lityle John, 2005)

Aristoteles memiliki dua asumsi tentang efektivitas persuasi yakni:

(1) untuk menciptakan persuasi yang efektif, komunikator membutuhkan tiga kemampuan yakni: etos, pathos, dan logos. (2) Komunikator harus mengenali audiens dari public speaking yang dijalankan. Ethos adalah kemampuan persuader menunjukkan keahlian dan kehendak baiknya. Pathosadalah kemampuan melibatkan dan membangun emosi dengan audiens. Serta logos adalah kemampuan persuader menyusun argumentasi yang logis dan rasional. Aristoteles juga menyatakan diperlukan 5 prinsip penting yang harus dilakukan oleh komunikator (Larson 2006, Griffin 2010, Turner and West).

Teori retorika menyebutkan bahwa:

Efektifitas persuasi ditemtukan oleh kualitas komunikator yang memiliki kemampuan untuk menyampaikan buktu etos, pathos, dan logos. Hal lainnya sebagai penentu keberhasilan komunikator adanya konsep kredibilitas, kompetensi, daya Tarik fisik, daya Tarik interpersonal. Asumsi bahwa faktor narasumber sebagai penentu keberhasilan persuasi semakin diperkuat dengan beberapa penelitian yang menghasilkan temuan bahwa ketika seorang komunikator memiliki kredibilitas yang tinggi maka argumentasi pesan (bukti) tidak lagi penting (O Keefe 1990). Demikian juga, ketika bukti atau argumentasi yang kuat menjadi tidak bernilai ketika persuader gagal dalam penyampaiannya (Larson, 2006).

Retorika secara umum didefinisikan sebagai seni berbicara dan sebuah teknik menggunakan bahsa baik tertulis maupun oral untuk menginformasikan, mempersuasi, dan memotivasi khalayak. Retorika berhubungan erat dengan komunikasi persuasive, maka Morissan dan Andy Corry Wardhani menyatakan bahwa segala hal yang dilakukan manusia ialah menggunakan symbol untuk mempengaruhi siapa saja yang ada di dekatnya dan membangun dunia dimana mereka tinggal (Morrisan, 2009). Tokoh lain ialah George Kennedy dalam Douglas Robinson, menyatakan retorika ialah "The energy inherent in emotions and thought, transmitted throught a system of signs, including language to other to influence their decisions or actions.

Dari defines di atas, retorika dapat dipahami sebagai seni berbicara yang digunakan oleh seseorang untuk menyampaikan pengetahuan, informasi, dan permasalahan kepada public yang bertujuan membangun kepercayaan, sehingga tujuan yang dimaksud akan tercapai.

Analisis retorika dalam penelitian ini menggunakan 5 prinsip retorika dari Cicero atau Canon Retorika Cicero, yang terdiri dari invention (penciptaan) terkait pemilihan topic, arrangement (pengaturan) terkait susunan dan perencanaan strategi teks, style (gaya) terkait gaya bahasa, memory (ingatan) terkait penggunaan alat- 
alat yang dapat membantu audiens untuk mengingat wacana dan delivery (penyampaian) terkait media. Retorika memiliki tujuan, yaitu:

1. To inform, menerbitkan penerangan dan pengertian kepada massa, guna memberikan penerangan yang mampu menanamkan pengertian dengan sebaik-baiknya

2. To convince, meyakinkan dan menginsafkan

3. To inspire, yaitu menimbulkan inspirasi dengan teknik dan system penyampaian yang baik dan bijaksana

4. To entertain ialah menggambarkan, menghibur, atau menyenangkan dan memuaskan

5. To actuate (to put into action) ialah menggerakkan dan mengarahkan mereka untuk bertindak menetralisir dan melaksanakan ide yang telah dikomunikasikan oleh pembicara di hadapan massa (Tasmara, 1987).

\section{Stand Up Comedy}

Secara definisonal oleh Greg Dean, stand up comedy adalah konten yang menampilkan isu-isu sosial yang terjadi di lingkungan sekitar masyarakat. Para pelaku stand up comedy atau comica ini juga selalu menampilkan sindiran-sindiran tentang apa yang dia alami dalam kehidupan sehari-hari dan dirasa membuat comica resah, namun ada pembedanya yaitu dibawakan secara komedi tunggal. Sebagai seorang seniman, kamu memiliki sebuah harta tak ternilai yang tidak dimiliki orang lain yaitu perspektiv dirimu tentang hal-hal yang memang menarik opini dan juga perasaanmu, beri kejujuran, masalah penonton setuju atau tidak itu tidak penting. Sesuai dengan definisi di atas bahwa, stand up comedy ditujukan untuk menampilkan dan mengkritisi isu-isu sosial di lingkungan masyarakat.

Stand Up Comedy adalah sebuah acara komedi yang dibawakan seorang pelawak di atas panggung kemudian melakukan monolog di depan audiensnya dan menyampaikan suatu topik atau materi. Seseorang yang melakukan Stand Up Comedy disebut sebagai comic. Dalam sejarahnya, Stand Up Comedy muncul pada abad ke 18 di Eropa dan di Amerika. Para comic ini biasanya memberikan beragam cerita humor, lelucon pendekatau kritik-kritik berupa sindiran terhadap sesuatu hal yang sifatnya cenderung umum dengan berbagai macam sajian gerakan dan gaya. Beberapa comic pun bahkan menggunakan alat peraga untuk meningkatkan performa mereka di atas panggung. (http://www.squidoo.com/Stand-Up-ComedyIndonesia-Jinggaberseri).

\section{Media Massa}

Menurut McLuhan (1967) media massa merupakan perpanjangan alat indra kita, sehingga kite bisa memperoleh informasi tentang segala hal yang belum pernah kita tahu sebelumnya. 
Media massa secara pasti memengaruhi pemikiran dan tindakan khalayak. Media massa pun tentu sangat bisa membentu opini publik untuk membawanya pada suatu perubahan yang signifikan. Dari sini saja sudah terbukti bahwa media massa dapat membentuk kristalisasi opini publik untuk khalayak dapat melakukan tindakan tertentu. Terkadang kekuatan media massa hanya sampai ranah sikap (Agee, 2001: 24-25). Media massa terutama televisi, memiliki peranan penting dalam transmisi sikap, persepsi dan kepercayaan

\section{New Media}

Media baru merupakan:

Istilah yang dipakai untuk semua bentuk media komunikasi massa yang berbasis teknologi komunikasi dan teknologi informasi. Media baru juga disebut media digital. Media digital adalah media yang kontennya berbentuk gabungan data, teks, suara dan berbagai jenis gambar yang disimpan dalam format digital dan disebarluaskan melalui jaringan berbasis kabel optik broadband, satelit dan sistem transmisi gelombang mikro (Flew, 2008: 2-3).

Berbicara tentang media baru, internet merupakan representasi yang paling canggih. Keberadaan media baru seperti internet bisa melampaui pola penyebaran pesan media tradisional.

New Media atau media baru adalah revolusi dari media lama dengan adanya tambahan perangkat teknologi dengan digitalisasi dan ketersediaan yang luas untuk penggunaan pribadi sebagai alat komunikasi. Terdapat karakter kunci untuk membedakan media lama dengan media baru dari perspektif pengguna, yaitu adanya interaktivitas, ditunjukkan oleh rasio respons atau inisiatif dari sudut pandang pengguna terhadap penawaran" sumber atau pengirim; kehadiran sosial atau sosiabilitas, dialami oleh pengguna, berarti kontak personal dengan orang lain dapat dimunculkan oleh penggunaan media; kekayaan media, jangkauan di mana media dapat menjembatani kerangka referensi yang jauh berbeda, mengurangi ambiguitas, memberikan lebih banyak petunjuk, melibatkan lebih banyak indra, dan lebih personal; otonomi, derajat di mana seorang pengguna merasakan kendali atas konten dan penggunaan, mandiri dari sumber; unsur bermain-main, kegunaan untuk hiburan dan kesenangan, sebagai lawan dari sifat fungsi dan alat; privasi, berhubungan dengan kegunaan media dan/atau konten tertentu; personalisasi, derajat di mana konten dan penggunaan menjadi personal dan unik (McQuail, 2011: 157).

\section{Metode Penelitian}

Metode penelitian ini ialah deskriptif kualitatif, dengan pendekatan analisis retoris. Analisis retoris merupakan bentuk analisis tekstual, fokus analisis retoris terdapat pada apa yang ingin disampaikan oleh komunikator dan bagaimana cara pengemasan dan penyampaian pesan tersebut sehingga dapat mempersuasi audiens. Analisis retorika dalam penelitian ini menggunakan 5 prinsip retorika dari Cicero atau Canon Retorika Cicero, yang terdiri dari invention (penciptaan) terkait pemilihan topik, arrangement (pengaturan) terkait susunan dan perencanaan strategi 
teks, style (gaya) terkait gaya bahasa, memory (ingatan) terkait penggunaan alat-alat yang dapat membantu audiens untuk mengingat wacana, dan, delivery (penyampaian).

Dalam penelitian ini, akan ada key informan dan juga informan. Key informan merupakan orang yang menguasai data atau fakta megenai penelitian. Peneliti tentunya telah memilih key informan yang memahami permasalahan yang peneliti angkat. Berikut adalah informasi mengenai key informan adalah Ardyansah Bhironk, Founder dari Stand Up Indo-Padang. Informan adalah Irlangga, anggota komunitas stand up Depok.

Ada tiga tahapan untuk teknik pengumpulan data penelitian kualitatif. (Emzir 2014:49)

1. Observasi (Pengamatan)

Alasan dibutuhkannya pengamatan atau observasi pada penelitian kualitatif adalah karena teknik pengamatan ini didasarkan pada pengalaman secara langsung. Peneliti juga dapat langsung mengamati bagaimana situasi yang terjadi di sekitar objek penelitian. Tentunya karena peneliti melihat dan mengamati sendiri sehingga akan langsung mencatat, hal-hal apa saja yang terjadi di sekitar objek penelitian. Keraguan yang terjadi oleh peneliti tentu bisa langsung mengecek kebenaran data yang ada. Sehingga dengan observasi, peneliti dapat memahami situasi rumit yang terjadi.

2. Wawancara

Wawancara merupakan bentuk komunkasi antara dua orang, melibatkan seseorang yang ingin memperoleh informasi dari seorang lainnya dengan mengajukan pertanyaan-pertanyaan berdasarkan tujuan tertentu (Mulyana 2013: 163). Sehingga diharapkan dengan dilakukannya wawancara mendalam, peneliti akan mendapatkan hasil penelitian yang maksimal.

Berdasarkan bentuk pertanyaannya, wawancara dibagi menjadi tiga yaitu tertutup, dimana pertanyaan yang diajukan merupakan pertanyaan yang menuntun jawaban tertentu. Pertanyaan terbuka, yang jawabannya tidak dibatasi sehingga peneliti bisa mendapat lebih banyak informasi. Dan ketiga pertanyaan tertutup terbuka, yang merupakan gabungan dari keduanya.

3. Studi Kepustakaan

Selain observasi dan wawancara, studi kepustakaan dapat mendukung dan juga melengkapi penelitian. Yaitu dengan cara mengumpulkan bahan dari buku dan juga referensi yang berkaitan dengan masalah.

\section{Teknik Pengolahan dan Analisis Data}

Menurut Moleong (2014:247) menyatakan bahwa proses analisis data diawali dengan menelaah seluruh data yang tersedia dari berbagai sumber, yaitu dari wawancara, pengamatan yang sudah dituliskan dalam catatan lapangan, dokumen pribadi, dokumen resmi, gambar, foto dan lain-lain.

Peneliti akan memilih analisis data kualitatif model Miles dan Huberman. Menurut Miles dan Huberman (1984) ada tiga kegiatan dalam analisis data kualitatif, yaitu:

1. Reduksi data, melihat pada proses pemilihan, pemfokusan, penyederhanaan, abstraksi dan pentranformasian data mentah yang terjadi di lapangan. 
2. Model data (Data display), merupakan kumpulan informasi yang tersusun yang memboleh pendeskripsian kesimpulan dan pengambilan tindakan.

3. Penarikan/Verifikasi kesimpulan, dalam tahap ini mulai memutuskan apakah ada sesuatu, mencatat keteraturan, pola-pola, penjelasan, konfigurasi yang mungkin, alur kausal dan proposisi-proposisi. Peneliti harus dapat menyimpulkan kesimpulan yang harus didapat, memelihara kejujuran dan kecurigaan, sehingga saat penelitian dimulai, samar dan meningkat menjadi eksplisit dan mendasar (dalam Emzir 2014: 129-133).

\section{Teknik Keabsahan Data}

Triangulasi adalah teknik pemeriksaan keabsahan data yang memanfaatkan sesuatu yang lain. Maka dapat disimpulkan bahwa triangulasi, dilakukan dengan melakukan perbandingan dengan data lain. Untuk dapat melakukan triangulasi, maka peneliti dapat melakukan dengan: mengajukan berbagai macam variasi pertanyaan, mengeceknya dengan berbagai sumber data, dan memanfaatkan berbagai metode agar pengecekan kepercayaan data dapat dilakukan. Triangulasi yang digunakan adalah triangulasi sumber.

\section{Pembahasan \\ Invention (Penciptaan)}

Comics, sebelum memulai stand up comedy para comics menciptakan materi. Tema apa yang akan dipilih, memggunakan teknik apa. Siapa yang akan menjadi audience-nya. Termasuk juga kostum apa yang akan digunakannya. "Biasanya, kita ngobrol-ngobrol dulu dengan anggota komunitas. Ngobrol santai aja. Tapi biasanya di kepala saya sudah ada semacam mapping yang sesuai tema". Ujar Ardhiansyah Bhironk, Founder Komunitas Stand Up Indo-Padang. "Gak perlu ngomong ke anak-anak kalo saya mw bikin materi dengan tema ini. Bukan begitu. Justru ide-ide unik dan segar bisa lahir dari obrolan santai" lanjutnya lagi. (wawancara dengan Ardiansyah Bhironk di Cibubur, Jakarta-Timur, 21 November 2018).

Dalam proses penciptaan materi ini, dapat dikatakan membutuhkan waktu. "Yah, semacam riset informal dulu. Kalau saya menyebutnya tes pasar. Coba nih kalo saya ngomong begini anak-anak komunitas bisa nangkep maksudnya nggak. Pada ketawa apa pada komentar garing". Apabila komunitas menunjukkan respon seperti yang diharapkan oleh comic, maka materipun dilanjutkan. "Jangan sampai kita tidak tau apa yang disampaikan ketika tampil. Gak mesti mengalaminya sendiri, pengalaman orang lain juga bisa menjadi bahan. Namun yah itu tadi, harus ada emosional kita dengan peristiwa yang diceritakan tersebut".

Lebih lanjut dituturkan oleh Bhirong bahwa dalam penciptaan materi harus ada 'goal'-nya. "Memang ketika tampil, bahasannya itu kemana-mana. Pertama ngomongin tentang sekolah, terus ngomongin tentang pacaran, terus harga 
sembako. Tapi sebenarnya yang disampaikan itu ada benang merahnya. Ada kaitannya. Nah, yang tadi itu misalnya, benang merahnya adalah membandingkan zaman dahulu saya dengan zaman now. Dari urusan pribadi, pendidikan, dan meluas ke permasalahan social. Tetap saja ada tema besarnya arahnya kemana." Penciptaan materi ini memegang peranan dasar dalam stand up comedy. Materi yang dibawakan akan menentukan bagaimana cara dan performa para comics ketika tampil.

\section{Arrangement (Pengaturan)}

Menurut West \& Turner (2007: 343), Aristoteles merasa bahwa seorang pembicara harus mencari pola penataan pesan yangmeningkatkan efektivitas pidato mereka. Dalam penataan pidato ini, dibagi dalam tiga bagian, yakni: introduction, body dan conclusion. Stand Up Comedy dalam penampilannya juga memperhatikan pengaturan. Pengaturan yang dimaksud dalam konteks ini adalah susunan materi dan teknik yang akan digunakan.

Materi seperti pada naskah pidato pada umumnya yakni ada pembukaan, isi, dan penutup. Maka naskah pada materi stand up comedy juga demikian. "Ada ice breaking-nya juga. Pernah nyimak kan kalo comics setelah mengucapkan salam terus bilang, ya kamu yang pakai baju pink. Aduh senyumnya manis banget. Nah, itu salah satu teknik ice breaking." Dalam stand up comedy, ada berbagai macam teknik. Namun ada teknik dasar yang harus dikuasi oleh comics, yang menjadi teknik dasar untuk mempelajari stand up comedy yakni premis, set up dan punchline.

Premis adalah adalah pokok bahasan yang ingin disampaikan kepada penonton. Set up adalah pengantar ke bagian yang lucu untuk menggiring asumsi penonton. Sementara punchline adalah yang mematahkan asumsi itu. Termasuk pada pengaturan ini yaitu pengaturan panggung. "Setting lampu, kostum juga diperhatikan. Justru karena penampilan satu orang jadi harus all out. Membuat kita berfikir bagaimana caranya supaya bisa jadi center point. Challenge aja gitu. Panggungnya besar, terus yang tampil Cuma satu orang. Kan itu perlu penampilan khusus yah" sambung Bhironk lagi.

Dari wawancara tersebut, penulis memahami bahwa tak ubahnya seperti pidato. Orator perlu mngatur naskah, penampilan, teknik dalam menyampaikan pesan kepada publik. Pengaturan materi yang baik akan membuat materi lebih mudah diterima dan dipahami oleh publik. 


\section{Style (Gaya)}

Pada pemikiran Aristoteles, Style berkaitan dengan penggunaan bahasa untuk menyampaikan ide dalam cara tertentu. Termasuk pemilihan kata, penggunaan perumpamaan, dan kepantasan kata. Menurut Bhironk, saat ini masyarakat sudah mulai kritis dalam menyoroti tentang kepantasan bahasa dan tema yang dibawakan para comics. Pria 35 tahun ini menganggap hal ini sebagai sebuah tantangan dari semakin dikenalnya Stand Up Comedy di Indonesia. Style adalah cara penggunaan bahasa dalam mengekspresikan ide.

Penggunaan style yang efektif akan membuat pesan lebih jelas, menarik dan powerful. Sebagai persuader yang efektif, diharapkan dapat menggunakan bahasa yang secara efektif meyuarakan argument. Penggunaan bahasa harus sungguhsungguh diperhatikan sehingga tidak menimbulkan pemahaman yang salah. Menurut West \& Turner penggunaan istilah yang aneh atau sudah ketinggalan jaman sebaiknya dihindari

"Terlebih ketika bahasa yang digunakan berkaitan dengan bidang agama maupun suku. Wah udah deh rasanya salah terus. Diprotes sama warga net. Bahkan gak jarang si comics langsung ramai-ramai dibully di media sosial". Jelas pria yang sudah tertarik dengan stand up comedy sejak bangku SMA ini. Seperti kasus yang pernah menimpa Joshua Suherman ketika menyoroti fenomena umat minoritas di Indonesia. Warga net langsung ramai-ramai memojokkan Joshua, bahkan ramairamai melakukan ajakan untuk memboikot acara yang menampilkan Joshua Suherman.

"Begini, materi yang disampaikan dalam stand up itu memang temanya bebas. Tidak ada batasan. Nah, termasuk tentang apa yang diterima umat minoritas di Indonesia yang disampaikan oleh Joshua. Lelucon satir. Tertawapun mikir. Dalam hati ada ungkapan "owh iya yah..." tapi ya itu tadi, masyarakat yang tidak memahami konteks Stand Up Comedy langsung saja menganggap itu salah. Liat konteks nya terlebih dahulu.".

Menurutnya Joshua juga tampil dalam kesempatan off air, namun karena ada yang menguploadnya jadi yah begini. Kalo analisa saya yang ditanyakan justru tujuan orang yang menguploadnya. Peristiwa ini menurut Bhironk menjadi pembelajaran bagi para comics. Bahwa penggunaan perumpamaan dan bahasa dalam materi menjadi hal yang perlu dianalisa betul oleh para comic.

\section{Memory (Ingatan)}

Dalam Stand Up Comedy, memory menjadi satu tujuan dari stand up comedy. Memory atau ingatan adalah hal yang ingin dicapai oleh para comic. Pesan yang sampai kepada audiens menjadi tujuan utama. Pesan yang mampu diingat oleh audiens berarti pesan yang baik. "Kan tujuan utama dari kita ngomong di depan 
audience yah supaya pesannya mengena dan diingat oleh mereka. Kalau sampai ada perubahan pandangan dan prilaku itu akan tambah buat kita seneng. Bonus.”. papar Bhironk lagi.

Memory berhubungan dengan kemampuan untuk mengingat mengenai apa yang akan kita katakan. Pada zaman dahulu, hal iniberarti mempelajari cara untuk mengingat ide dalam urutan untuk kita mempresentasikan mereka dengan bahasa yang kita rencanakan. Padamasa kini, hal ini lebih kepada bagaimana menggunakan catatan atau manuskrip dari pada menghapal secara keseluruhan.

\section{Delivery (Penyampaian)}

Termasuk penyampaian dalam konteks stand up comedy adalah pemilihan media. "Justru awal-awal itu stand up comedy lebih memilih youtube. Karena lewat youtube itu materi stand up gak kena sensor. Bebas aja" ujar Bhironk sambil tertawa. Menentuka media apa sebagai saluran dalam menyampaikan materi itu menjadi satu hal yang dipertimbangkan. "Percuma kita udah bikin materi bagusbagus, terus tampil di tv, eh pesannya gak ngena. Salah satu sebabnya bisa jadi dari media yang salah. Mungkin saluran TV nya yang tidak sesuai dengan materi yang disampaikan. Misalnya nih, stand up comedy yang tayang di Metro TV sama stand up comedy yang tayang di Indosiar. Materi yang disampaikan beda. Nah itu maksudnya, kalau mau bawain tema A di TV B dan kalau mau bawain tema B di TV A." jelas pria yang punya hobby koleksi helm ini.

Delivery merupakan cara final dari retorika. Delivery melibatkan secara vokal dan fisik dalam mempresentasikan speech kita. Delivery sangat penting karena orang lebih memperhatikan ide yang dipresentasikan secara menarik dan powerful. Delivery seharusnya mempresentasikan ide sesuai bobotnya dan tidak untuk. membuat ide lemah tampil lebih kuat. Menurut West \& Turner (2007: 347), delivery merupakanpresentasi non verbal dari seorang pembicara. Di dalamnya terdapat kontak mata, tekanan suara, pengucapan, dialek, gerakan tubuh dan penampilan fisik.

\section{Etos, Pathos, dan Logos dalam Retorika}

Retorika mampu memanipulasi pilihan orang lain, atau mempengaruhi pikiran seseorang untuk mendukung atau melawan sebuah ide. Dalam logos, persuader harus melihat bagaimana audience mengolah data evidence secara logis sehingga mencapai suatu kesimpulan. Bukti logis. Logos menarik sisi rasional dari manusia, dan bergantung pada kemampuan pendengar dalam memproses. Ethos didapat karena individu tersebut mendapatkan hak untuk berbicara dengan kompetensi, kelayakan, dinamis, dan landasan yang sama, keahlian personal, karisma, 
personalitas, ketulusan pembicara, dapat dipercaya dan perhatiannya pada kebaikan audiens. Pathos, atau bukti emosional. Mempersuasi orang secara emosional lebih cepat diterima dari pada secara logika. Untuk menggunakan pathos, seorang pembicara harus memahami hal-hal berikut: 1) keadaan pikiran / state of mind dari audiens, 2) Arah tentangan emosi mereka, 3) Sebab mereka merasakan hal tersebut.

Comics, dalam menyampaikan materinya juga dilihat dari ketiga hal tersebut. Misalnya ketika materi yang akan disampaikan adalah tentang dunia kampus. Seorang comics adalah benar mahasiswa. Sehingga materi yang disampaikan mengena bagi para penonton dan dekat dengan keseharian mahasiswa. Apabila yang menyampaikannya bukan mahasiswa tentulah akan berbeda dan tidak sesuai dengan realita. Itu sebabnya dalam stand up comedy sudah ada para comics dan spesialisasi topik yang dibawakannya. Contohnya: Raditya Dika tentang status single dan kegalauan remaja akan pasangan. Pandji Pragiwaksono membawakan tentang politik dan persatuan bangsa, Ernest Prakasa identik dengan permasalahan Tionghoa. Meskipun para comics bebas untuk membawakan tema apapun namun menurut peneliti tetap saja ada ciri khas dan hal yang dikuasainya.

\section{Stand Up Comedy dan Media Sosial}

Perkembangan media sosial belakangan mulai mengubah tatanan sosial. Social menjadi individual. Tak terkecuali dalam stand up comedy. Seperti disampaikan dalam wawancara key informan dengan peneliti, bahwa stand up comedy tidak dapat dipisahkan dari media social. Raditya Dika misalnya, beberapa tahun terakhir bahkan sempat dinobatkan sebagai youtuber dengan viewer terbanyak. Konten nya sebagian besar adalah stand up comedy. Hal ini membuktikan bahwa penikmat youtube yang didominasi generasi millennial memang menyukai stand up comedy. Raditya Dika merupakan selebriti serta YouTuber terpopuler di Indonesia. Subscriber penulis buku 'Kambing Jantan' itu sudah mencapai lebih dari 3,3 juta. Berdasarkan Social Blade, estimasi penghasilan Raditya Dika per tahun sekitar US\$ 46 ribu hingga US\$ 739 ribu atau Rp 623 juta sampai Rp 10 miliar. (www.cnbcindonesia.com)

Kesuksesan Raditya Dika ini menjadi inspirasi para generasi millennial untuk bercita-cita menjadi comic. Fenomena ini memicu para generasi millennial berlomba-lomba untuk menjadi 'lucu' tampil di youtube. "Ini yang bener-bener lucu, banyak anak zaman now punya satu karya stand up comedy terus mereka langsung menyebut dirinya comics. Viral sedikit materinya, langsung dibilang kalo ini comics" cerita Bhironk lagi. Menurutnya, untuk disebut comics perlu membangun eksistensi diri dulu. Itulah sebabnya peranan komunitas menjadi penting. "Di dalam komunitaslah seorang comics dibentuk dan membangun citranya. Apabila baru tampil di media social, menurut saya sih nanti dulu deh" sambungnya lagi. 
Belakangan, bahkan stasiun televisi Kompas TV dan Metro TV membuat ajang pencarian bakat comics. Para calon comics diberikan pembekalan tentang dunia stand up comedy. Mulai dari pembuatan materi, penciptaan karakter, hingga delivery. Mereka difasilitasi untuk tampil, dan diberikan masukan oleh para comics senior atau selebritis. Bahkan tak jarang, apabila stasiun televisi tersebut memiliki program acara, para jebolan acara pencarian bakat ini dilibatkan (mendapat peranred).

Media sosial menjadi pedang bermata dua bagi para comics. Memiliki sisi positif dan negatif. Sisi positifnya yaitu sebagai ladang penghasilan, sementara sisi negatifnya yaitu memperburuk karya stand up comedy tersebut. "Para comic professional itu selalu menginginkan ada pembelajaran dari apa yang dismapaikannya. Hasil akhirnya bukan hanya bikin orang ketawa atau nyinyir garing. Tapi ada sesuatu yang buat audience notice". Dijelaskan lebih lanjut menurut Angga, anggota komunitas Standup Depok. (wawancara dengan Irlangga, anggota komuniktas stand up Depok, di Limo-Depok pada 22 November 2018), bahwa sebagai penikmat stand up comedy kadang suka miris saja apabila ada comics yang lebih mementingkan supaya akun youtube nya di 'subscribe'. "Memang kreatifitas di youtube itu tanpa batas.

Apalagi beberapa youtuber berpengaruh di Indonesia salah satunya kontennya stand up comedy. Tapi bukan lantas pada latah dan menyebut kontennya juga stand up comedy. Padahal secara materi dan teknik belum bisa disebut sebagai comics. Akibatnya yah masyarakat yang kurang paham langusng punya kesimpulan bahwa stand up comedy tidak mendidik, bahasanya kasar, menjelek-jelekan fisik orang".

Lebih lanjut masih menurut Angga lagi, ada beberapa konten yang membuat masyarakat memandang negatif. "Yang paling baru yaitu konten tentang memasak daging babi dan kurma. Kalau saya lihat sih yang bikin masyrakat meributkan hal itu ucapan si creatornya. Meskipun si creator mau menggambarkan tentang toleransi, tapi bahasa yang dipilihnya kurang tepat, jadi yah saya sebagai penikmat juga jadi mikir. Ini apa sih maksudnya" sambung pria yang akrab disapa Aghe ini.

Media sosial memang menjadi media yang akrab dengan para comics dalam melakukan pertunjukkan stand up comedy. Para comic bisa menciptakan konten kreatif dalam materi yang disampaikan. Namun hendaknya tak lepas dari etika di media sosial. Bahwa ada jutaan viewer yang menyaksikannya. Mengacu kepada teori aristoteles, khususnya canon retorika. Hal tersebut dapat diterapkan oleh para comics sebelum mengunggah kontennya di youtube. "Pada dasarnya tujuan stand up comedy itu dapat membangun kesadaran dan membuat lebih peduli pada masalah sosial sekitar" sambung angga lagi. 


\section{Simpulan}

Dari pembahasan tersebut, peneliti menyimpulkan: Bahwa stand up comedy merupakan sebuah retorika. Hal ini dilihat dengan menggunakan canon retorika, yakni Invention, Arrangement, Style, Memory, dan Delivery.

Kekuatan stand up comedy melalui materi yang disampaikan dan style nya membuat generasi millennial tertarik, sehingga stand up comedy digunakan sebagai salah satu cara mengemukakan pendapat dan membangun keadaan social dengan cara yang menghibur pesatnya perkembangan media social turut membentuk stand up comedy menemukan saluran lain untuk menunjukkan kreatifitasnya. Tak jarang dari media social seorang comic menjadikannya sebagai lading penghidupan. Hal ini jga turut menarik minat generasi millennial untuk menjadi youtuber dengan konten kreatif stand up comedy.

\section{Referensi}

Berger, A. A. 2000. Media and Communication Research Methods. Thousand Oaks: Sage Publications. Bungin, B. (2001). Metodologi Penelitian Kualitatif. Jakarta: RajaGrafindo Persada.

Creswell, J. W. 1998. Qualitative Inquiry and Research Design Choosing Among Five Traditions. London: Sage Publications. Crowley, S., \& Hawhee, D. (2004). Ancient Rhetorics for Contemporary Students (third edition). New York

Pearson Longman Education. Crowley, S., \& Hawhee, D.2004. From Ancient Rhetorics for Contemporary Students 3rd edition.

Pearson Longman. Effendi, O. U. 1981. Dimensi-dimensi Komunikasi. Bandung: Alumni.

Effendy, O. U. 1989. Kamus Komunikasi. Bandung: Penerbit Mandar Maju.

Fiske, J. 1990. Cultural and Communication Studies: Sebuah Pengantar Paling Komprehensif. Bandung: Jalasutra.

Horner, W. B. 2000. Reinventing Memory and Delivery. In M. D. Goggin, Inventing Discipline: Rhetoric Scholarship in Honor of Richard E. Young. Urbana: National Council of Teachers of English

Littlejohn, Stephen W \& Karen A. Foss. 2009. Teori Komunikasi, edisi 9, Jakarta: Salemba 
Morissan. 2013. Teori Komunikasi: Individu hingga Massa. Jakarta: Kencana Prenadamedia Group.

Morissan dan Wardhani, Andy Corry. 2009. Teori Komunikasi tentang Komunikator, Pesan, Percakapan, dan Hubungan. Bogor: Ghalia Indonesia.

McQuil, Denis. 2011. Teori Komunikasi Massa, edisi 6. Jakarta: Salemba

Mulyana, D. 2010. Metodologi Penelitian Kualitatif. Bandung: Remaja Rosdakarya

Rosda. Munandar, H., \& Suherman, M. 2016. Aktivitas Komunikasi Pemerintahan Ridwan Kamil di Media Sosial.

Pusat Pembinaan dan Pengembangan Bahasa. 2004. Pedoman Umum Ejaan Bahasa Indonesia yang Disempurnakan. Yogyakarta:

Tera. Rakhmat, J. 2004. Metodologi Penelitian Komunikasi. Bandung: Rosdakarya. Sobur, A. 2006. Analisis Teks Media. Bandung: Remaja Rosdakarya. . 2009. Semiotika Komunikasi. Bandung: Remaja Rosdakarya.

Toto Tasmara.1987. Komunikasi Dakwah, Jakarta: Gaya Media Pratama, t,t), hal. 156

\section{Jurnal}

Yudi Perbawaningsih, Universitas Atmajaya Yogyakarta, Menyoal Elaboration Likelihood Model (ELM) dan teori retorika, jurnal ilmu komunikasi volume 9 nomor 1, juni 2012: 1-17)

Umaimah Wahid, Personal Branding Dan Retorika Komunikator Politik Pada Pemilukada Dki Jakarta 2017 (Analisis Retorika Atas Teks Pidato Sebagai Kandidat Gubernur Dan Wakil Gubernur Pada Penentuan Nomor Urut Peserta Pemilu), Prosiding Seminar asional Komunikasi Publik dan Dinamika Masyarakat Lokal Volume III, 2016, Universitas Bandar Lampung.

Hj. Kismiyati El Karimah, Rumawan Erlandia, Talitha Nindia Rahma, Pola Retorika Ridwan Kamil Dalam Twitter Prosiding Seminar asional Komunikasi 
Publik dan Dinamika Masyarakat Lokal Volume III, 2016, Universitas Bandar Lampung.

\section{Internet}

https://www.kaskus.co.id/thread/53375a3c5674d8fb4f0000d7/8-nama-yang-palingberpengaruh-dari-stand-up-comedy-di-indonesia/

https://www.republika.co.id/berita/nasional/umum/18/01/16/p2n18f282-sejarahstand-up-comedy-masuk-indonesia

http://www.academia.edu/15492980/SEJARAH_AWAL_BERDIRINYA_STAND _UP_COMEDY_DI_DUNIA

https://celebrity.okezone.com/read/2018/03/05/33/1868251/banyaknya-kompetisiturut-serta-memajukan-stand-up-comedy-indonesia

https://www.brilio.net/selebritis/selain-jago-stand-up-5-komika-ini-ternyata-jugaseorang-penyiar-radio- $181004 \mathrm{~m} . \mathrm{html}$ 